\title{
PRINSIP-PRINSIP EKONOMI ISLAM DALAM INVESTASI SYARIAH
}

\section{Ina Nur Inayah}

inanurinayah.71@gmail.com

\begin{abstract}
ABSTRAK
Salah satu karunia Allah kepada manusia sebagai bekal hidup adalah harta . Islam tidak melarang penggunaan harta secara konsumtif namun tetap harus mengupayakan sisi produktifitas. Salah satu upaya tersebut produktifitas harta adalah dengan investasi. Investasi adalah sebuah komitmen untuk menyimpan harta atau dana yang diharapkan akan mendapatkan keuntungan di masa yang akan datang. Kegiatan investasi ini sangat dianjurkan dalam Islam sebagaimana dinyatakan dalam AlQuran dan dipraktikan oleh Nabi SAW. Hal itu dikarenakan banyak sekali manfaat yang ditimbulkan selain sebagai penjagaan diri, juga karena harta yang diinvestasikan tidak bertumpuk hanya pada seseorang tapi terdistribusi sehingga menambah nilai dan manfaat harta. Namun tidak semua investasi boleh dilakukan, Islam sebagai agama yang mengatur semua aspek kehidupan manusia, memiliki prinsip-prinsip yang dapat dijadikan batasan dan aturan dan membedakan mana investasi yang halal dan yang haram. Aturan tersebut meliputi jenis usaha, transaksi dan modalnya. Sehingga dengan memahami prinsip-prinsip tersebut umat Islam akan terhindar dari praktik muamalah yang dilarang. Karena sejatinya Islam memandang investasi tidak hanya sebagian aktifitas muamalah maliyah semata tetapi memiliki nilai ibadah bila tetap pada koridor aturan dan prinsip-prinsip Syariah.
\end{abstract}

Kata Kunci : Investasi, prinsip-prinsip, ekonomi Syariah. 


\section{PENDAHULUAN}

Islam menganjurkan umatnya selalu berusaha untuk mendapatkan kehidupan yang baik karena terselenggaranya kehidupan yang baik di dunia menjadi salah satu penunjang tercapainya kehidupan yang baik juga di akhirat dan salah satu upaya untuk mewujudkannya adalah melalui kegiatan investasi. Investasi merupakan salah satu obyek kajian dari muamalah maliyah. Investasi diartikan sebagai suatu usaha menempatkan dana dengan tujuan mendapatkan keuntungan di waktu yang akan datang. Selain itu investasi juga dapat dikatakan sebagai suatu kegiatan pengelolaan aset atau kekayaan dengan orientasi tertentu yang di dalamnya terdapat strategi untuk mencapai tujuan tersebut.

Investasi menurut ekonomi Syariah adalah menempatkan dana dengan tujuan mendapatkan keuntungan dengan cara dan berdasarkan prinsip-prinsip syariah. Invstasi yang sesuai dengan prinsip Syariah Islam adalah investasi yang halal dan tidak mengandung unsur riba, maysir dan gharar.

Dalam Al Quran terdapat beberapa ayat yang secara tidak langsung berkenaan dengan investasi di antaranya pada QS Yusuf: 46-49 dan QS al Hasyr : 18 dan QS Lukman: 34 yang dipahami sebagai usaha mempersiapkan dan menjaga diri. Pada QS al Isra: 26-27 dan QS al Furqan: 67 tentang larangan berlaku boros dan membatasi pengeluaran konsumtif. QS Annisa: 9 menjaga sikap dengan hat-hati dan perhitungan terhadap generasi yang akan datang yang lebih baik. Hadits riwa- yat Abu Daud tentang kebolehan mengadakan perdamaian selama tidak dilakukan untuk menghalalkan sesuatu yang haram dan mengharamkan yang halal. Kaidah fikih yang menyatakan kebolehan pada semua kegiatan muamalah sebelum ada larangan yang mengharamkannya.

Investasi secara ekonomi memiliki banyak manfaat di antaranya tercipta lapangan usaha dan lapangan pekerjaan, distribusi harta, adanya pengamanan dana dan pertambahan pada nilai asset. Saat ini banyak sekali jenis investasi yang ditawarkan baik investasi pada sektor keuangan maupun non keuangan yang menawarkan berbagai keuntungan tanpa memperhatikan kehalalan dan kemashlahatannya karena itu kita harus bersikaf selektif karena tidak semua investasi diperbolehkan dalam Islam meskipun investasi tersebut menguntungkan.

Supaya umat Islam tidak terjebak pada praktik investasi yang dilarang dan agar tujuan investasi dapat tercapai maka agama Islam mimiliki teori dan konsep yang mengatur seluruh aktifitas manusia dengan memberikan panduan serta prinsip-prinsip yang berdasarkan pada sumber hukum Islam dalam bermuamalah. Tulisan ini akan mendiskusikan prinsipprinsip ekonomi Islam dalam berinvestasi dengan menggunakan metode deskriptif dan studi litelatur.

\section{PEMBAHASAN}

\section{Landasan Syar'i Investasi}

Beberapa landasan syar'i baik dari Al Quran, Hadits Nabi saw. maupun kaidah 
fikih yang melandasi kebolehan investasi diantaranya:

Firman Allah dalam QS Al Hasyr ay at 18 :

"Wahai orang-orang yang beriman bertaqwalah kepada Allah dan hendaknya setiap orang memeperhatikan apa yang telah diperbuatanya untuk hari esok (akhirat) dan bertaqwalah kepada Allah sungguh Allah Maha teliti terhadap apa yang kamu kerjakan".

QS Lukman ayat 34:

"Sesungguhnya hanya di sisi Allah ilmu tentang hari kiamat;dan Dia yang menurunkan hujan dan mengetahui apa yang ada dalam Rahim. Dan tidak ada seorangpun yang dapat mengetahui dengan pasti apa yang akan dikerjakannya besok. Dan tidak ada seorangpun yang dapat mengetahui di bumi mana ia akan mati. Sungguh Allah Maha Mengetaui, Maha Mengenal".

QS An-Nisaa ayat 9:

"Dan hendaklah takut kepada Allah orang-orang yang sekiranya mereka meninggalkan keturunan yang lemah di belakang mereka yang mereka khawatir terhadap kesejahteraannya. Oleh sebab itu hendaklah mereka bertaqwa kepada Allah dan hendaklah mereka bertutur kata yang benar".

Ayat-ayat di atas meskipun tidak secara langsung memerintahkan investasi namun tujuannya sejalan dengan tujuan investasi yaitu anjuran bagi orang-orang yang beriman un- tuk mempersiapkan kehidupan yang lebih baik dan sejahtera dimasa yang akan datang dengan memperhatikan setiap sikap dengan penuh ketelitian karena Allah Zat Yang Maha Teliti. Sikap ini didorong oleh cita-cita kelak generasi yang akan datang menjadi generasi yang kuat dan kewaspadaan agar generasi yang akan datang tidak menjadi generasi yang lemah baik spiritual maupun materi.

Hadits Nabi SAW yang artinya: “Tidak boleh membahayakan diri sendiri dan membahyakan orang lain". (HR Ibnu Majah dari Ubadah bin Shamit dari Yahya).

Kaidah fikih yang menyatakan pada dasarnya segala bentuk kegiatan muamalah boleh dilakukan sebelum ada dalil yang melarangnya.

Fatwa DSN-MUI No.20/DSN-MUI/IV/ 2001 tentang Pedoman Pelaksanaan Investasi Reksadana Syariah.

\section{Investasi dalam Perspektif Ekonomi Islam}

Ekonomi syariah adalah usaha atau kegiatan yang dilakukan oleh orangperorang, kelompok, badan usaha yang berbadan hukum atau tidak berbadan hukum dalam rangka memenuhi kebutuhan yang bersifat komersial menurut prinsip syariah ${ }^{1}$. Menurut Dr. Muhammad Abdullah al Arabi, ekonomi syariah merupakan sekumpulan dasardasar umum ekonomi yang disimpulkan

1 Lihat Pasa 1 ayat 1 Kompilasi Hukum Ekonomi Syariah.

Jurnal Ilmu Akuntansi dan Bisnis Syariah

91

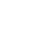


dari Al Quran dan Sunnah dan merupakan bangunan perekonomian yang didirikan di atas landasan dasar-dasar tersebut sesuai dengan lingkungan di masanya $^{2}$. Sedangkan menurut Abdul Manan ekonomi syariah adalah ilmu pengetahuan sosial yang yang mempelajari rakyat yang di ilhami oleh nilai-nilai Islam $^{3}$.

Menurut penjelasan Pasal 49 Huruf (i) Undang-undang No. 3 Tahun 2006 tentang Pengadilan agama yang dimaksud dengan ekonomi Syariah adalah perbuatan atau kegiatan usaha yang dilaksanakan menurut prinsip Syariah, antara lain meliputi (a) bank Syariah; (b) lembaga keuangan mikro; (c) asuransi Syariah; (d) reasuransi Syariah; (e) reksadana Syariah; (f) obligasi Syariah dan surat berharga berjangka menengah Syariah; (g) sekuritas Syariah; (h) pembiayaan Syariah; (i) pegadaian Syariah; (j) dana pensiun lembaga keuangan Syariah; (k) bisnis Syariah. Berdasarkan Undang-Undang Pasal 49 Huruf (i) di atas salahsatu yang termasuk pada kegiatan ekonomi syariah adalah investasi syariah.

Islam menganjurkan umatnya untuk berinvestasi dalam rangka mempersiapkan diri menghadapi berbagai kemungkinan di masa yang akan datang dengan bersikap tidak boros dan penuh perhitungan dalam penggunaan harta dengan harapan mendapatkan bertambahnya

\footnotetext{
2 Ahmad Muhammad al Assal dan Fathi Abdul Karim, Sistem Ekonomi Islam; Prinsip-Prinsip dan Tujuannya( Surabaya: PT Bina IImu, 1980)hlm.11.

3 Muhammad Abdul Manan, Teori dan Praktik Ekonomi Islam, (Yogyakarta: Dana Bhakti Wakaf, 1993, hlm351.
}

aset. Selain itu investasi juga memberikan keuntungan berupa keamanan dana keuntungan materi sehingga dapat meningkatkan kesejahteraan masyarakat karena harta dapat terdistribusi luas berupa modal.

Pada kenyataannya masyarakat dihadapkan pada dua kenyataan di sisi lain terdapat golongan masyarakat dengan tingkat kemampuan finansial yang tinggi namun kurang memiliki kemampuan manajerial yang baik atas pengelolaan harta, pada sisi yang lain sebagian masyarakat yang memiliki keahlian namun secara finansial memilki keterbatasan. Berdasarkan beberapa hal di atas maka kepentingan investasi semakin dapat diterima.

Dari segi bahasa investasi berasal dari bahasa Inggris dari kata investmen kata dasar invest ${ }^{4}$ artinya menanam. Dalam bahasa Arab investasi dikenal dengan istilah istitsmar ${ }^{5}$ yang bermakna menjadikan berbuah dan bertambah jumlahnya. Dalam kamus istilah pasar modal keuangan investasi diartikan sebagai penanaman uang atau modal dalam suatu perusahaan atau proyek dengan tujuan memperoleh keuntungan. ${ }^{6}$ Investasi digambarkan sebagai suatu usaha menyimpan dana dengan tujuan akan mendapatkan keuntungan. Harapan mendapatkan keuntungan merupakan factor utama dalam investasi (Sitompul: 2007).

\footnotetext{
4 Ahmad Anthoni K. Muda . Kamus Lengkap Ekonomi (Gitamedia Press,2003) hlm.195.

5 Bank Indonesia Kamus Istilah Keuangan dan Perbankan Syariah, hlm 30

6 Zainal Arifin, Dasar-Dasar Managemen Bank Syariah (Jakarta: Alfabet,2003),h.7
} 
Investasi menurut ekonomi Islam adalah penanaman dana atau penyertaan modal untuk suatu bidang usaha tertentu yang kegiatan usahanya tidak bertentangan dengan prinsip-prinsip syariah, baik objeknya maupun prosesnya7. Investasi Syariah adalah investasi yang tidak mengandung unsur perbuatan maysir, gharar dan riba juga patuh pada aturanaturan yang ditetapkan kaidah fikih muamalah dan kesepakatan para ulama yang tertuang dalam fatwa .Secara umum sebuah kegiatan investasi selalu bertujuan mendapatkan keuntungan dengan bertambah nilai aset, tidak ada seorang investor yang menginginkan kerugian. Dan bukan sesuatu yang dilarang dalam Islam segala bentuk kompensasi yang menguntungkan atas segala pemanfaatan modal, barang maupun keahlian yang dilakukan oleh pihak lain (Chapra,1999).

Adapun Konsep keuntungan sendiri dalam pandangan Islam memiliki makna yang menyeluruh meliputi:

1. Aspek material atau finansial. Artinya adalah segala bentuk keuntungan ditandai dengan bertambahnya nilai pada aset..

2. Aspek kehalalan. Artinya agar hasil yang diperoleh dalam investasi halal, maka investasi yang dipilih juga harus halal baik usaha maupun prosedurnya.

3. Aspek sosial dan lingkungan. Artinya suatu bentuk investasi hendaknya memberikan manfaat dan kontribusi positif bagi masyarakat ba-

7 Jurnal Ekonomi Islam - Volume 8, Nomor 2 (2017). nyak dan lingkungan sekitar, baik untuk generasi saat ini maupun yang akan datang.

4. Aspek pengharapan kepada rida Allah. Artinya investasi dilakukan dengan tujuan akhir mendapat rida Allah (Chair: 2015).

Alokasi Investasi pada dapat dilakukan pada dua sektor:

1. Investasi pada aset real / rael asset adalah investasi pada golongan benda benda yang tidak bergerak atau aset tetap. Contohnya tanah, proferti, logam mulia, mengelola perusaha sendiri.

2. Investasi pada aset keuangan/financing asset adalah investasi yang ditanamkan pada lembaga keuangan seperti pada perbankan dan pasar modal contohnya deposito, saham ,reksadana Syariah dan sukuk. Terkait dengan investasi sektor keuangan ini tercatat ada beberapa fatwa yang telah dikeluarkan DSNMUI diantaranya:

a. Fatwa No. 20/DSN-MUI/IX/2001 tentang Pedoman pelaksanaan Investasi untuk Reksadana Syariah

b. Fatwa No. 32/DSN-MUI/IX/2002 tentang Obligasi Syariah

c. Fatwa No 33/DSN-MUI/IX/2002 tentang Obligasi Syariah Mudharabah

d. Fatwa No.40/DSN_MUI/X/2003 tentang Pasar Modal dan Pedoman Umum Penerapan Prinsip Syariah di Bidang Pasar Modal

e. Fatwa No.41/DSN-MUI/III tentang Obligasi Syariah Ijarah 
f. Fatwa No. 59/DSN-MUI/V/2007 tentang Obligasi Syariah Mudharabah Konversi

g. Fatwa No.65/DSN-MUI/III/2008 tentang Hak memesan Efek Terlebih Dahulu (HMETD) Syariah

h. Fatwa No.66/DSN-MUI/III/2008 tentang Waran Syariah

i. Fatwa No.69/DSN-MUI/VI/2008 tentang SBSN

Kegiatan investasi keuangan menururt ekonomi Syariah pada dasarnya adalah kegiatan yang dilakukan oleh pemilik harta (investor) terhadap pemilik usaha (emiten) untuk memberdayakan pemilik usaha dalam melakukan kegiatan usahanya dimana pemilik harta (investor) berharap akan memperoleh manfaat tertentu karena itu kegiatan investasi pada dasarnya memiliki kesamaan dengan kegiatan usaha yang lainnya yaitu harus memelihara prinsip kehalalan dan keadilan. ${ }^{8}$

Dalam praktiknya investasi Syariah pada sektor keuangan memiliki term akad yang biasa digunakan diantaranya:

a. Menggunakan akad musyarakah atau akad kerjasama antar dua pihak atau lebih dalam suatu usaha tertentu dengan penyertaan modal tertentu dengan kesepakatan-kesepakatan tertentu.

b. Menggunakan akad mudharabah adalah kerjasama antar dua orang atau lebih dimana pemilik modal mempercayakan modalnya pada

8 Iwan P. Pontjowinoto,Prinsip Syariah di Pasar Modal (Pandangan Praktisi) Jakarta, Modal Publication: 2003, hlm.45. pengelola (mudharib)dengan kesepakatan pembagian keuntungan. Dengan komposisi dana $100 \%$ dari shahibul maal dan keahlian dari mudharib. ${ }^{9}$

c. Menggunakan akad ijarah atau sewa yaitu akad yang memindahkan hak guna atau manfaat obyek ijarah dalam waktu tertentu tanpa diikuti oleh pemindahan kepemilikan.

d. Menggunakan akad kafalah yaitu perjanjian antarpihak penjamin dan pihak yang dijamin (Orang yang berutang) untuk menjamin kewajiban pihak yang dijamin kepada pihak lain (pihak yang berpiutang)

e. Menggunakan akad wakalah perjanjian pihak pemberi kuasa dan penerima kuasa untuk melakukan tindakan tertentu.

Islam adalah agama yang pro-investasi dan menganjurkannya karena di dalam ajaran Islam sumber daya (harta) yang ada tidak hanya disimpan tetapi harus diproduktifkan, sehingga bisa memberikan manfaat kepada umat (Hidayat 2011). Dan dengan investasi terjadi penyebaran harta secara fungsional di masyarakat. Lebil lanjut Ahmad Gozali menguraikan alasan penting investasi, yaitu:

1. Karena pertumbuhan aset atau kenaikan penghasilan tidak seimbang dengan perkembangan keluarga, ter-

${ }^{9}$ Adiwarman A.Karim, Bank Islam Analisis Fikih Dan Keuangan ( Jakarta: PT RajaGrafindo Persada: 2010),h.103 
masuk jumlah anak yang harus dibiayai pendidikannya

2. Karena nilai aset kita akan tergerus oleh inflasi. Yaitu penurunan nilai mata uang yang ditandai, salah satunya dengan kenaikan harga barang dan kebutuhan sehari-hari. inflasi gaya hidup juga mempengaruhi nilai aset kita.

3. Karena diri kita tidak selamanya muda dan sehat, sehingga suatu saat kita harus pensiun bekerja. Untuk keperluan itu, dibutuhkan sejumlah dana agar kita bisa menutupi biaya hidup di hari tua nanti.

4. Karena kita ingin meninggalkan keluarga dan anak cucu dalam keadaan kuat secara ekonomi. (Qs an Nisa: 9)

Agar Tidak terjerumus pada praktik investasi yang tidak sesuai dengan ajaran Islam dan menghindari berbagai risiko, maka ada beberapa hal yang menjadi dasar dan prinsip-prinsip dalam berinvestasi.

\section{Prinsip-Prinsip Ekonomi Syariah dalam Investasi}

Yang diaksud dengan prinsip-prinsip syariah dalan investasi adalah prinsipprinsip yang berdasarkan hukum Islam dalam pelaksanaan investasi. Islam menganjurkan umatnya untuk melakukan muamalah termasuk investasi. Investasi dalam Islam selain bertujuan pada keuntungan finansial dan keuntungan social juga tidak boleh mengabaikan etika, hukum ${ }^{10}$ dan prinsip-prinsip Syariah

Investasi merupakan bagian dari aktifitas muamalah karena itu padanya berlaku kaidah muamalah segala sesuatunya boleh dilakukan selama tidak ada dalil yang melarang atau mengharamkannya (Dzajuli: 2006) artinya kegiatan investasi dibolehkan menurut syar'i selama dijalankan atas dasar dan dengan cara-cara yang tidak diharamkan agama baik dalam transaksi, jenis usaha, proses maupun dampaknya. Secara umum praktik muamalah dalam kajian ekonomi syariah memiliki azas-azas sebagai berikut :

1. Pada dasarnya segala bentuk muamalah adalah boleh dilakukan sebelum ada dalil yang melarangnya.

2. Muamalah dilakukan atas dasar sukarela tanpa ada unsur paksaan (al hurriyyah)

3. Muamalah dilakukan atas dasar mendatangkan manfaat dan menghindari madharat.

4. Muamalah dilakukan atas dasar keadilan (a'dalah). (Basyir: 2000)

Prinsip adalah turunan dari nilai yang bersifat implementatif, konkrit, dan spesifik bahkan terkadang sebagian bersifat umum prinsip bisa dijadikan landasan berpikir dan menentukan arah dalam mencapai sebuah tujuan ${ }^{11}$. Menururt Atang Abd. Hakim prinsip memiliki

10 Dalam Kajian Hukum Juhaya S.Praja menyebutkan tujuh prinsip yang dijadikan landasan dalam Hukum Islam: Prinsip tauhidullah, amr ma'ruf nahyi munkar, al adalah,al hurriyyah, al musawah, attaawwun dan tsasamu.

11 Dr.H.M Arifin Hamid,S.H., M.H . Hukum Ekonomi Islam Di Indonesia 
makna yang sama dengan hukum. Prinsip merupakan asas atau fondasi kebenaran yang menjadi pokok dasar pijakan bagi seseorang untuk berfikir dan bertindak ${ }^{12}$.

Yang dimaksud prinsip disini adalah prinsip yang berdasarkan pada hukum Islam dalam investasi yang secara operasional disusun pada fatwa yang merupakan produk hukum para pihak yang memiliki kewenangan di bidang ekonomi Syariah. Secara khusus Fatwa DSN-MUI No.80/DSNMUI/III/2011 mengatur bagaimana memilih investasi yang dibolehkan syariat dan melarang kegiatan yang bertentangan dengan prinsip syariah dalam kegiatan investasi dan bisnis, yaitu:

a. Maisīr, yaitu setiap kegiatan yang melibatkan perjudian dimana pihak yang memenangkan perjudin akan mengambil taruhannya;

b. Gharar, yaitu ketidakpastian dalam suatu akad, baik mengenai kualitas atau kuantitas objek akad maupun mengenai penyerahannya;

c. Riba, tambahan yang diberikan dalam pertukaran barang-barang ribawi (al-amwāl al-ribawiyyah) dan tambahan yang diberikan atas pokok utang dengan imbalan penangguhan imbalan secara mutlak;

d. Bāțil, yaitu jual beli yang tidak sesuai dengan rukun dan akadnya (ketentuan asal/ pokok dan sifatnya) atau tidak dibenarkan oleh syariat Islam;

12 Muhammad Ali, Kamus Lengkap Bahasa Indonesia Modern. (Jakarta: Pustaka Amani.t.t) hlm 324. e. Bay'i ma'dūm, yaitu melakukan jual beli atas barang yang belum dimiliki;

f. Iḥtikār, yaitu membeli barang yang sangat dibutuhkan masyarakat (barang pokok) pada saat harga mahal dan menimbunnya dengan tujuan untuk menjual kembali pada saat harganya lebih mahal

Selain itu, ada beberapa prinsip syariah khusus terkait investasi yang harus menjadi pegangan bagi para investor dalam berinvestasi (Aziz 2010), yaitu:

a. Tidak mencari rezeki pada sektor usaha haram, baik dari segi zatnya (objeknya) maupun prosesnya (memperoleh, mengolah dan medistribusikan), serta tidak mempergunakan untuk hal-hal yang haram;

b. Tidak menzalimi dan tidak pula dizalimi (la tazlimūn wa lā tuzlamūn);

c. Keadilan pendistribusian pendapatan;

d. Transaksi dilakukan atas dasar rida sama rida ('an-tarāọin) tanpa ada paksaan;

e. Tidak ada unsur riba, maysīr (perjudian), gharar (ketidakjelasan), tadlīs (penipuan), gharar (kerusakan/kemudaratan) dan tidak mengandung maksiat.

Kegiatan investasi memiliki manfaat yang tidak hanya dirasakan langsung oleh investor yaitu berupa pengamanan dana juga keuntungan yang akan meng- 
akibatkan pada pertambahan nilai asset tetapi dampak yang luas bagi perekonomian akan tetapi tidak lantas semua investasi boleh dilakukan karena itu 1dalam pelaksanaanya Islam memberikan batasan dan aturan aturan yang jelas mana investasi yang boeh dan tidak boleh supaya manusia terjaga dari perbuatan yang akan merugikan dirinya maupun masyarakatnya. Di sisi lain keuntungan yang diperoleh tidak sebatas keuntungan materi saja tapi keuntungan yang mencakup seluruh aspek aspek finansial, kehalalan, aspek sosial dan aspek pengharapan kepada rida Allah. Artinya investasi dilakukan dengan tujuan akhir mendapat rida Allah (Chair: 2015).

Agar investasi memperoleh keuntungan sebagaiman tersebut di atas sejatinya kegiatan investasi berangkat dari :

a. Rabbani, prinsip ini mendasari bahwa alam dan semua isinya ada dalam pengaturan dan kepemilikan Allah. Keyakinan bahwa semuanya milik Allah dan ada dalam pengaturan-Nya juga keuntungan yang menjadi tujuan investasi hakikatnya milik Allah dan dalam kekuasaan Allah, maka selanjutnya ia akan meminta karunia itu pada pemiliknya dengan ikhtiar melakukan prosedurnya yang sejalan dengan aturan-Nya. Pada tataran teknis prinsip ini akan memposisikan Allah sebagai saksi (syahid) dan pengawas (raqib) diantar para pihak, baik antara Investor dan emiten maupun emiten dengan pa- ra karyawannya. Hal ini sejalan dengan makna hadits qudsi berikut:

"Aku adalah pihak ketiga dari dua orang yang bersyarikat selama satu pihak tidak mengkhianati yang lainnya, bila salah satu berkhianat maka Aku (Allah) pasti meninggalkan mereka berdua". (HR.Abu Daud, ad Daruquthni, dan al Hakim mensahihkannya).

b. Halal, yaitu terhindar dari yang syubhat dan haram meliputi: 1) Niat atau motivasi; 2) Transaksi, transaksi bisnis (al 'aqdu muamalah) yang dibenarkan Syariah adalah yang memenuhi beberapa syarat berikuta;

1) Para pihak yang bertransaksi adalah mereka yang memiliki kesadaran dan pemahaman akan bentuk dan konsekwensi transaksi tersebut, memiliki hak untuk melakukan transaksi baik atas nama dirinya sendiri maupun atas nama orang lain.

2) Barang atau jasa yang yang ditransaksikan adalah benda atau jasa yang halal yang diketahui karakteristiknya oleh para pihak.

3) Bentuk transaksi jelas baik secara lisan maupun tulisan dan dipahami oleh para pihak yang terlibat.

4) Adanya kerelaan dari para pihak yang terlibat dalam transaksi tersebut

c. Prosedur Pelaksanaan Transaksi 
d. Jenis Barang atau jasa yang ditransaksikan

e. Penggunaan Barang atau jasa yang ditransaksikan

f. Mashlahah (bermanfaat bagi masyarakat). Asas mashlahah merupakan hal yang esensial dalam bermuamalah dalam Islam proses dan hasil akhir yang proporsional dan berkeadilan adalah tujuan yang diinginkan Islam. Para pihak yang terlibat dalam investasi masing-masing harus memperoleh manfaat sesuai dengan porsinya dan manfaat itu lebih jauh lagi harus dapat dirasakan pula oleh masyarakat pada umumnya. Seluruh tindakan transaksi yang memungkinkan akan mendatangkan keuntungan yang sementara namun akan menimbulkan kerugian dari sisi moril adalah investasi yang yang dilarang agama karena tidak berdampak pada kemashlahatan. Selain itu ada praktik-praktik yang nampak menguntungkan bagi segelintir orang namun secara bersamaan merugikan pihak yang lebih banyak di sisi lain.

Prinsip-prinsip ekonomi Syariah dalam investasi adalah landasan yang dijadikan aturan hukum dalam menentukan arah pelaksanaan kegiataan investasi yang bersumber pada Syariah Islam. Adiwarman Karim ${ }^{13}$ dalam tulisannya

13 Adiwarman Karim dalam Bukhori yusuf dan Iman santoso, Syariat Islam di Indonesia antara Peluang dan yang berjudul Penerapan Syariat Islam di Bidang Ekonomi mengemukakan beberapa prinsip-prinsip ekonomi Islam terdiri:

1) Prinsip Aqidah, Qs al Maidah: 17 yang artinya, "Kepunyaan Allahlah segala apa yang ada di langit dan di bumi dan apa yang terdapat diantara keduannya", Qs al-Maidah: 120 dan Qs anNuur: 33.

2) Prinsip al Adalah, Qs al Hujurat: 9 artinya, "Sesungguhnya Allah menyukai orang-orang yang berlaku adil "

3) Prinsip Nubuwwah Qs Maryam: 56-57 artinya "Segala sesuatu yang dari Allah dan RasulNya pasti benar dan hanya kebenaran.

4) Prinsip Khilafah Qs al Hajj:41 artinya "Pemimpin yang mendapat petunjuk akan selalu mendororng kebaikan dan mencegah pada kemunkaran. Dalam hal ini penmerintah memegang peranan penting dalam kegiatan ekonomi.

5) Prinsip $M a^{\prime} a d$ terungkap dalam Qs al Qasas:77 artinya," Carilah akhiratmu dan janganlah melupakan duniamu"

Prinsip adalah elemen pokok yang menjadi struktur atau kelengkapan sesuatu (UII 2013). Adapun prinsip syariah yang dimaksud dalam tulisan ini adalah prinsip hukum Islam yang bersumber pada al Quran dan hadits dalam kegiatan

Tantangan, Ad (Jakarta: Globalmedia Cipta Publishing, 2004)hlm,79-112 
ekonomi khususnya investasi karena kegiatan investasi merupakan bagian dari bermuamalah māliyah, adapun prinsipprinsip fikih muamalah sebagaimana dikemukakan Dr. Koko adalah sebagai berikut $^{14}$ :

1) Allah adalah pemilik mutlak semua harta

2) Al halal bayyin wa al Haram al bayyin

3) Al infaq (spending) dan $A l$ Kasab (Earning)

4) Al Mashalih wa al Mafasid

5) Antarodhin Minkum

6) Mabrur Transaction

Dari uraian di atas dapat dipahami bahwa Islam sangat menganjurkan investasi tapi bukan semua bidang usaha diperbolehkan dalam berinvestasi. Aturan-aturan di atas menetapkan batasanbatasan yang halal atau boleh dilakukan dan haram atau tidak boleh dilakukan. Tujuannya adalah untuk mengendalikan manusia dari kegiatan yang membahayakan diri sendiri dan masyarakat serta agar harta yang diinvestasikan mendapatkan keuntungan dari segala aspek yang akan mendatangkan berkah dari Allah,bermanfaat bagi orang banyak sehingga mencapai falāh (sejahtera lahirbatin) di dunia juga di akhirat.

\section{SIMPULAN}

Demikian tulisan sederhana tentang prinsip-prinsip ekonomi Syariah dalam

\footnotetext{
14 Disampaikan pada perkuliahan Fiqh Muamalah.
}

investasi. Dalam kajian ekonomi Syariah investasi termasuk dalam kajian muamalah karena itu berlaku kaidah fikih semuanya boleh dilakukan selama tidak ada dalil yang melarangnya. Investasi adalah kegiatan menyimpan dana dengan tujuan mendapatkan keuntungan, faktor utama dalam investasi adalah keuntungan, bertambahnya asset baik riil maupun financing. Sebagai suatu aktifitas ekonomi setiap orang yang berinvestasi pasti memiliki tujuan mendapatkan laba yang sebesar-besarnya, jaminan masa depan,memproteksi diri, memperoleh passive income untuk mewujudkan keinginan dan tujuan akhir yang baik.

Islam sebagai agama yang membawa ajaran untuk seluruh manusia yang dapat diterapkan secara applicable pada semua aspek kehidupan yang selalu sejalan dengan segala kondisi dan zaman. Islam memiliki aturan-aturan yang harus dijadikan pedoman termasuk dalam investasi supaya investasi tidak hanya menguntungkan secara materil tapi menguntungkan juga dari sisi spiritual (falah) bermanfaat untuk masyarakat umum dan bernilai ibadah sehingga melahirkan ketenangan lahir batin dunia dan akhirat.

Investasi haruslah tetap berada pada jalur syariat yang mengajarkan untuk berinvestasi yang dijalankan sesuai dengan nilai-nilai dan ajaran ajaran yang bersifat Rabbani, memeberikan manfaat yang lebih besar dibandingkan dengan mudharat yang ditimbulkan dijalankan pada usaha dan dengan prosedur yang halal. Semua transaksi yang terjadi harus atas dasar suka sama suka, tidak ada unsur pemak- 
saan, tidak ada pihak yang didzalimi atau mendzalimi. Tanpa unsur riba, maysir dan gharar tidak bersifat spekulatif serta harus transparan.

Hanya Investasi yang sesuai dengan prinsip ekonomi Islam dan prinsip muamalah yang mendapat legalitas secara syar'i baik dari al Quran, hadits (praktik Nabi) dan kesepakatan hasil ijtihad para ulama. Islam telah mengatur suatu mekanisme dalam pengembangan harta, serta menjelaskan hukum-hukum yang harus dipatuhi atau yang dilarang untuk diker- jakan, dan salah satu usaha untuk pengembangan harta kekayaan itu adalah melalui kegiatan investasi Syariah. Investasi Syariah adalah investasi yang dijalankan dengan berdasarkan pada prinsip-prinsip Syariah yaitu investasi yang tidak hanya berorientasi profit semata tapi ada nilai kemashlahatan dan falah atau keuntungan dunia dan akhirat. Investasi yang berdasar pada prinsipprinsip Syariah adalah investasi yang berprinsip pada nilai- nilai Islam dan hal hal yang disepakata oleh para ulama .

\section{DAFTAR PUSTAKA}

Abdul Manan, Muhammad. Teori dan Praktik Ekonomi Islam,( Yogyakarta: Dana Bhakti Wakaf,1993

Ahmad Muhammad al Assal dan Fathi Abdul Karim, Sistem Ekonomi Islam; PrinsipPrinsip dan Tujuannya Surabaya: PT Bina Ilmu, 1980

Ali, Muhammad. Kamus Lengkap Bahasa Indonesia Modern. (Jakarta: Pustaka Amani.t.t)

Anthoni, Ahmad K. Muda . Kamus Lengkap Ekonomi (Gitamedia Press,2003)

Bank Indonesia Kamus Istilah Keuangan dan Perbankan Syariah

Hakim, Atang Abd. Fiqih Perbankan Syariah Transformasi Fiqih Muamalah Ke Dalam Peraturan Perundang-

Hamid, Arifin, S.H., M.H . Hukum Ekonomi Islam Di Indonesia. (Ghalia Indonesia,2007)

Jurnal Ekonomi dan Bisnis Islam (Journal of IslamicEconomics and Business) Volume 1, Nomor 1, Mei 2016

Jurnal Ekonomi Islam - Volume 8, Nomor 2 (2017).

Karim, Adiwarman. Dalam Bukhori yusuf dan Iman santoso, Syariat Islam di Indonesia antara Peluang dan Tantangan, Ad (Jakarta: Globalmedia Cipta Publishing, 2004).

Karim, Adiwarman. Sejarah Pemikiran Ekonomi Islam. (Jakarta: PT RajaGrafindo Persada, 2004)

Bank Islam Analisis Fiqih dan Keuangan. (Jakarta: PT RajaGrafindo, 2004)

Ekonomi Islam Suatu Kajian Kontemporer. (Jakarta : Gema Insani Press, 2001)

Mardani, Hukum Ekonomi Syariah (Jakarta: Refika Aditama,2010)

Praja, Juhaya S. Filsafat Hukum Islam . (Bandung: LPP Unisba, 1995).

Sula, Syakir, Asuransi Syariah (Life and General) Konsep dan Sistem Oprasional, Jakarta agems Insani:2014.

Undangan . (Bandung: PT Rafika Aditama,2012). 